\title{
Genomic DNA Analysis of Rodent Mycoplasmas
}

\author{
Satoshi KUNITA, Eiji TERADA, Akira GHODA, Akira TAKAKURA*, \\ and Naoko KAGIYAMA* \\ Department of Laboratory Animal Science, School of Hygienic Sciences, Kitasato \\ University, Kitasato, Sagamihara, 228, Japan, and ${ }^{*}$ Central Institute for \\ Experimental Animals, 1430 Nogawa, Miyamae, Kawasaki, 213.
}

(Received 19 October 1988/Accepted 31 January 1989)

\begin{abstract}
Genomic DNA was compared between three typical species of rodent mycoplasmas, Mycoplasma pulmonis, $M$. arthritidis and $M$. neurolyticum, and between strains of these species. Each of the three species showed a distinct restriction endonuclease cleavage pattern of genomic DNA. The genetic heterogeneity of these species was revealed by total DNA hybridization as well. In addition, the restriction endonuclease cleavage pattern of genomic DNA was almost identical in three strains of $M$. pulmonis and in two strains of $M$. neurolyticum. The genetic homogeneity among strains of the same species was revealed by total DNA hybridization as well. These data suggest that the genomic DNA sequence of each rodent mycoplasma species has a high degree of species specificity.
\end{abstract}

The classification and identification of mycoplasmas are based on morphological, biochemical and serological characteristics. For some mycoplasma species in which serological identification is difficult, a method based on genetic characteristics has also been attempted. To assess genetic relatedness among prokaryotes, including mycoplasrnas, DNA-DNA homology studies have generally been used $[3,9,10]$. In recent years, with the spread of restriction endonucleases that recognize specific nucleotide sequences, the comparison of DNA cleavage patterns by these enzymes has proved to be a simple, useful method. DNA analysis based on restriction endonuclease cleavage pattern is highly appropriate for mycoplasmas, which have a very small genome, ca. 500 megadaltons. Although some studies have successfully identified mycoplasma species by this method $[1,8]$, the properties of genomic DNA of rodent mycoplasmas have not been determined.

In the present study, genomic DNAs were compared between three typical species of rodent mycoplasmas, Mycoplasma pulmonis, $M$. arthritidis and $M$. neurolyticum, according to their restriction endonuclease cleavage patterns and by total DNA hybridization.

\section{Materials and Methods}

Organisms and culture conditions: $M$. pulmonis $\mathrm{m} 53$ and $M$. neurolyticum Type A were kindly provided by $\mathrm{Dr}$. K. Koshimizu, Division of Animal Research, Faculty of Medicine, University of Tokyo, Japan. $M$. pulmonis $\mathrm{M} 4$ and $\mathrm{R} 1$, and $M$. arthritidis $\mathrm{PG} 6$ were generously provided by Dr. M. Nakagawa, Department of Veterinary Science, National Institute of Health, Japan. M. neurolyticum $\mathrm{H} 322$ was originally isolated from the lung of a mouse that was tested in the Central Institute for Experimental Animals, Japan. Mycoplasmas were cultured in Chanock's PPLO broth [2] at $37^{\circ} \mathrm{C}$ for 3 days. The organisms were harvested by centrifugation at $5,000 \times \mathrm{g}$ for 30 min, washed twice with saline-EDTA $(0.15 \mathrm{M}$ $\mathrm{NaCl} / 0.1 \mathrm{M}$ ethylenediamine tetraacetic acid,

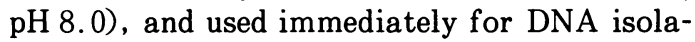
tion.

Isolation of mycoplasmal DNA : Genomic DNA was extracted and purified by a modification of the method of Marmur [5]. Briefly, organisms washed in saline-EDTA were lysed 
by the addition of sodium dodecyl sulfate (SDS) to a final concentration of $1 \%$. The lysates were treated for $30 \mathrm{~min}$ at $37^{\circ} \mathrm{C}$ with ribonuclease A (Sigma Chemical Co., St. Louis, Mo.) at a final concentration of $50 \mu \mathrm{g} / \mathrm{ml}$, then extracted twice with equal volumes of phenol saturated with TE buffer $(10 \mathrm{mM}$ Tris- $\mathrm{HCl}, \mathrm{pH}$ $8.0 / 1 \mathrm{mM}$ EDTA). The aqueous phase was separated by centrifugation at $5000 \times \mathrm{g}$ for 10 min, and the DNA was precipitated by adding two volumes of cold ethanol. The DNA precipitates were rinsed with $70 \%$ ethanol, and dissolved in TE buffer. The DNA concentration was estimated according to the absorbance measured at $260 \mathrm{~nm}$ by a spectrophotometer (LKB, Sweden), assuming that an absorbance of 1.0 at $260 \mathrm{~nm}$ corresponded to $50 \mu \mathrm{g}$ of DNA per $\mathrm{ml}$.

Restriction endonuclease cleavage pattern analysis : All restriction endonucleases used were purchased from Nippon Gene Co. (Toyama, Japan). About $5 \mu \mathrm{g}$ of mycoplasmal DNA was digested at $37^{\circ} \mathrm{C}$ for $2 \mathrm{hr}$ with $12-24$ units of each enzyme under the appropriate buffer conditions recommended by the supplier. The DNA digests were electrophoresed on $1 \%$ agarose gels in TBE buffer ( $89 \mathrm{mM}$ Tris $/ 89 \mathrm{mM}$ boric acid $/ 2.5$ $\mathrm{mM}$ EDTA, $\mathrm{pH}$ 8.2) at $100 \mathrm{~V}$ for $3 \mathrm{hr}$. The gels were stained with ethidium bromide and photographed under a UV transilluminator.

Total DNA hybridization procedure : Mycoplasmal DNA dissolved in TE buffer at $100 \mu \mathrm{g}$ $/ \mathrm{ml}$ was heat-denatured for $5 \mathrm{~min}$ in a boilingwater bath and cooled rapidly on ice. The denatured DNA was serially diluted in $2 \times$ SSC $(1 \times \mathrm{SSC}$ is $0.15 \mathrm{M} \mathrm{NaCl}$ plus $0.015 \mathrm{M}$ sodium citrate), and $1 \mu \mathrm{g}$ to $1 \mathrm{ng}$ of the DNAs was deposited under vacuum on nitrocellulose filters by a dot blot apparatus (ADVANTEC, Tokyo, Japan). The blotted filters were baked at $80^{\circ} \mathrm{C}$ for $2 \mathrm{hr}$, and incubated at $42^{\circ} \mathrm{C}$ for $3 \mathrm{hr}$ in prehybridization buffer $[50 \% \mathrm{v} / \mathrm{v}$ formamide, 5 $\times$ SSC, $5 \times$ Denhardt's solution $(1 \times$ Denhardt's solution contains $0.2 \mathrm{mg} / \mathrm{ml}$ each of bovine serum albumin, polyvinylpyrrolidone, and Ficoll-Sigma Chemical Co.), 0.5\% SDS, and $200 \mu \mathrm{g}$ of denatured calf thymus DNA (Pharmacia, Sweden) per $\mathrm{ml}$. The genomic DNAs of $M$. pulmonis $\mathrm{m} 53, M$. arthritidis PG 6, and $M$. neurolyticum Type A were labeled with $\left[\alpha-{ }^{32} \mathrm{P}\right]$ deoxycytidine triphosphate by the multiprime DNA labeling system (Amersham, England). The labeled DNAs were heat- denatured and mixed with the prehybridization buffer at a final concentration of $5 \mathrm{ng} / \mathrm{ml}$, and used as the hybridization mixtures. Hybridization was carried out in the hybridization mixures at $42^{\circ} \mathrm{C}$ overnight. The filters were then washed twice in $2 \times \mathrm{SSC} / 0.1 \% \mathrm{SDS}$ at room temperature and twice in $0.1 \times \mathrm{SSC} / 0.1 \% \mathrm{SDS}$ at $65^{\circ} \mathrm{C}$, dried, and autoradiographed.

\section{Results}

Restriction endonuclease cleavage patterns of genomic DNA : Figure 1 shows the genomic DNA cleavage patterns of $M$. pulmonis $\mathrm{m} 53$, $M$. arthritidis PG 6 and $M$. neurolyticum type A obtained with various restriction endonucleases. Genomic DNAs of all three species were cleaved to varying degrees by EcoRI, HindIII, PstI and BamHI, and each of the three species showed a distinct cleavage pattern. The number of cleavage bands obtained with PstI (recognition site CTGCAG) and BamHI (GGATCC), which recognize the guaniner-pluscytosine $(G+C)$-rich sequences, was less than that obtained with EcoRI (GAATTC) and HindIII (AAGCTT), which recognize the adenine-plus-thymine $(A+T)$-rich sequences. No or very few cleavage bands were found when Smal was used.

The DNA cleavage patterns of the three strains of $M$. pulmonis, the one strain of $M$. pulmonis, the one strain of $M$. arthritidis and the two strains of $M$. neurolyticum were compared by using HindIII, which produced the largest number of cleavage bands, and PatI, which produced the characteristic cleavage patterns for each species, with a small number of bands. After digestion with HindIII, DNAs from the three strains of $M$. pulmonis and DNAs from the two strains of $M$. neurolyticm showed a remarkably similar cleavage pattern, but it was difficult to determine the details of the differences between strains because of the large number of cleavage bands (Fig. 2-A). When PstI was used, the DNA cleavage patterns of the three strains of $M$. pulmonis were almost identical, showing only minor variation. The cleavage patterns of the two strains of $M$. neurolyticum were identical (Fig. 2-B).

Total DNA hybridization test : Total DNA hybridization was carried out by using the DNA-DNA dot hybridization technique. As shown in Fig. $3-\mathrm{A}$, the ${ }^{32} \mathrm{P}$-labeled total geno- 


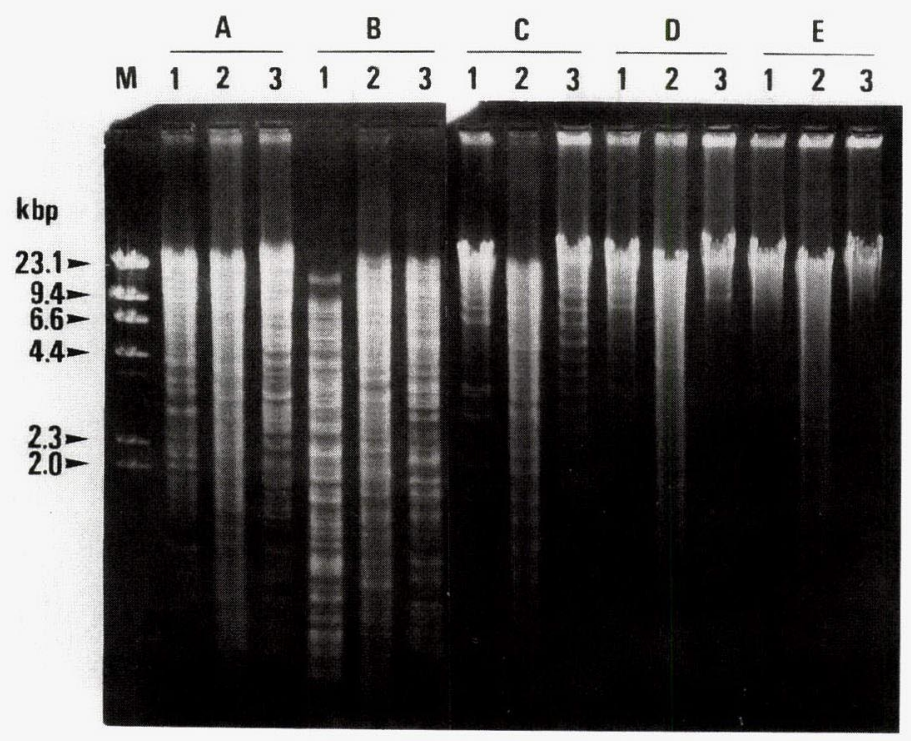

Fig. 1. Genomic DNA cleavage patterns of three rodent mycolasma species obtained with the restriction endonucleases EcoRI (A), HindIII (B), PstI (C), BamHI (D), and Smal (E) Lane 1: M. pulmonis m53 Lane 2: M. arthritidis PG 6 Lane 3: M. neurolyticum Type A Lane M contained HindIII-digests of $\lambda$ phage DNA as size markers

mic DNA of $M$. pulmonis m53 showed a hybridization signal to as little as $10 \mathrm{ng}$ of homologous $M$. pulmonis m 53 DNA. It also showed a hybridization signal of the same intensity to the DNA of $M$. pulmonis M 4 and R 1 strains. In contrast, it showed only weak hybridization with $1 \mu \mathrm{g}$ of DNA from $M$. arthritidis and $M$. neurolyticum. The ${ }^{32} \mathrm{P}$-labeled total genomic DNAs of $M$. arthritidis PG 6 and $M$. neurolyticum Type A also showed a hybridization signal to as little as $10 \mathrm{ng}$ of DNA from the same species, but only a weak signal to $1 \mu \mathrm{g}$ of DNA from different species (Fig. 3-B, C) .

\section{Discussion}

We compared genomic DNAs of three typical rodent mycoplasmas, $M$. pulmonis, $M$. arthritidis and $M$. neurolyticum, according to their restriction endonuclease cleavage patterns. Selection of the restriction endonuclease used for digestion of DNAs is important in analyzing restriction endonuclease cleavage patterns. Since DNAs of most mycoplasmas have a low $\mathrm{C}+\mathrm{C}$ content, the DNA cleavage pat- terns produced with restriction endonucleases that recognize $\mathrm{G}+\mathrm{C}$-rich sequences show a small number of bands, providing an easy comparison $[1,7]$. In agreement with these findings, our results also showed cleavage patterns that varied distinctly with the species when PstI was used, although the number of cleavage bands produced with BamHI and SmaI was extremely small. On the other hand, there were only slight differences in the restriction endonuclease cleavage patterns of genomic DNAs, despite differences in antigenicity found by the complement fixation test, between the three strains of $M$. pulmonis, m53, M 4 and R 1 [6]. Watson et al. [11] reported that the genomes of $M$. pulmonis strains were very closely related. Our findings are in agreement with their observations.

We also employed total DNA hybridization to examine the genetic relatedness of the three species of rodent mycoplasmas and among strains of the same species. The genetic relatedness among prokaryotes has been conventionally assessed on the basis of the DNA homology value determined by the quantitative 

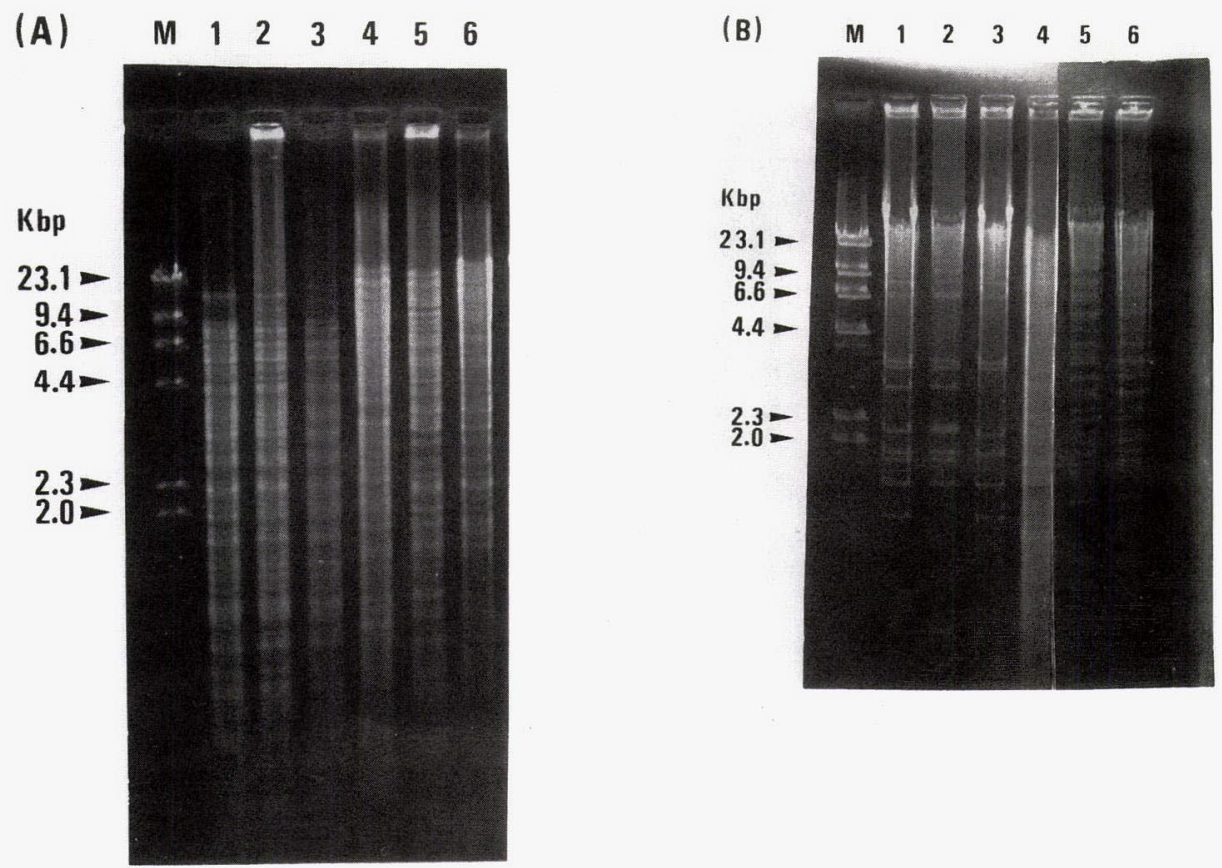

Fig. 2. Genomic DNA cleavage patterns of some strains of rodent mycoplasma species obtained with the restriction endonucleases HindIII (A) and PstI (B) Lane 1: M. pulmonis m53 Lane 2: M. pulmonis M4 Lane 3: M. pulmonis R1 Lane 4: $M$. arthritidis PG 6 Lane 5: $M$. neurolyticum Type A Lane 6: M. neurolyticum $\mathrm{H} 322$ Lane M contained HindIII-digests of $\lambda$ phage DNA as size marers

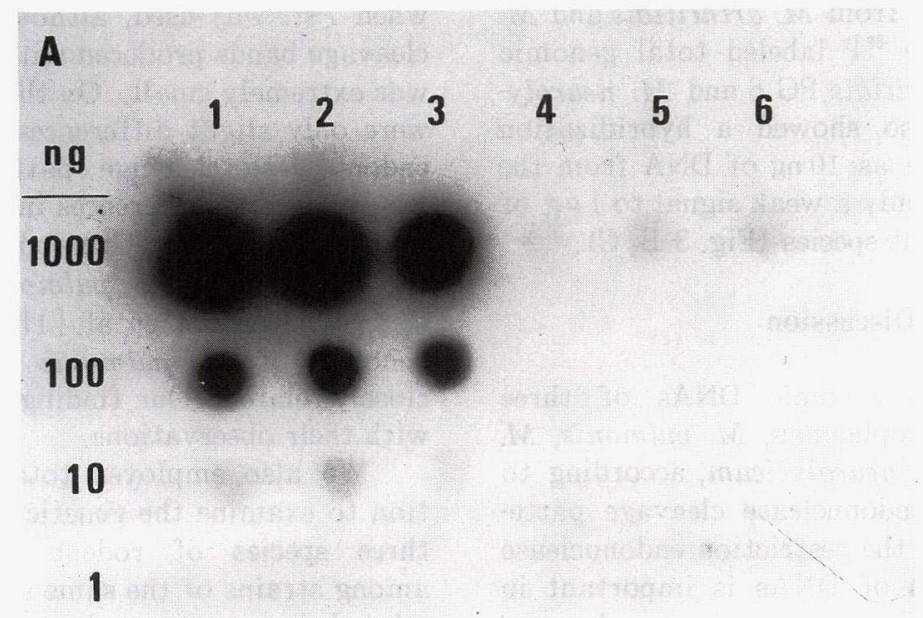



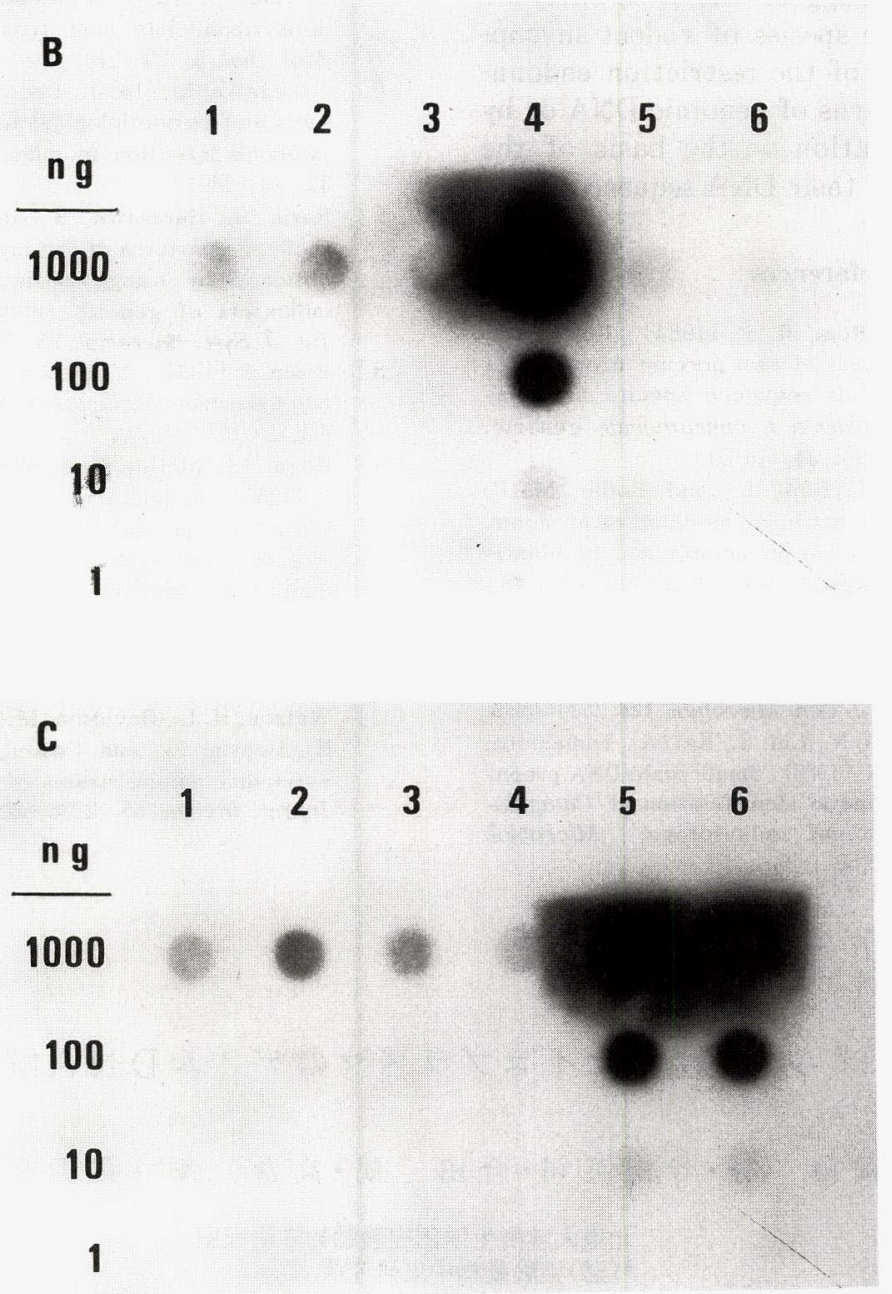

Fig. 3. DNA-DNA dot hybridization among rodent mycoplasmas. ${ }^{32} \mathrm{P}$-labeled total genomic DNA of $M$. pulmonis $\mathrm{m} 53(\mathrm{~A}), M$. arthritidis PG 6 (B), or $M$. neurolyticum Type A (C) was used for each hybridization test. The amount of target DNA in a dot is shown on the left side of each row. Lane 1: M. pulmonis m53 Lane 2: M. pulmonis M 4 Lane 3: M. pulmonis R 1 Lane 4: M. arthritidis PG 6 Lane 5: M. neurolyticum Type A Lane 6: M. neurolyticum $\mathrm{H} 322$

DNA-DNA hybridization test, but we carried out the DNA-DNA dot hybridization test. This test was simple and provided visually distinct results. Ezaki et al. [4] reported that the results obtained by this procedure were in good agreement with the DNA homology values. The DNA-DNA dot hybridization test revealed only weak cross-hybridization among the three species of rodent mycoplasmas, indicating considerable heterogeneity of these species. On the other hand, hybridization among the strains of $M$. pulmonis was strong, revealing the high degree of genetic homogeneity within this species. Similarly, $M$. neurolyticum strains showed remarkable genetic homogeneity. 
These findings suggest the possibility of identifying the three species of rodent mycoplasmas on the basis of the restriction endonuclease cleavage patterns of genomic DNA or by total DNA hybridization on the basis of the species specificity of their DNA sequences.

\section{References}

[1] Chan, H. W. and Ross, R. F. (1984). Restriction endonuclease analyses of two porcine mycoplasma deoxyribonucleic acids : sequence-specific methylation in the Mycoplasma hyopneumoniae genome. Int. J. Syst. Bacteriol., 34, 16-20.

[2] Chanock, R. M., Hayflick, L., and Barile, M. F. (1962). Growth on artificial medium of an agent associated with atypical pneumonia and its identification as a PPLO. Proc. Natl Acad Sci USA 48, 41-49.

[3] Christiansen, C. and $\operatorname{Ern} \phi$, H. (1982). Classification of the F 38 group of caprine mycoplasma strains by DNA hybridization. J. Gen. Mic robiol, 128, 2523-2526.

[4] Ezaki, T., Takeuchi, N., Liu, S., Kai, A., Yamamoto, H. and Yabuuchi, E. (1988). Small-scale DNA preparation for rapid genetic identification of Campylobacter species without radioisotope. Microbiol. Immunol, 32, 141-150.
[5] Marmur, J. (1961). A procedure for the isolation of deoxyribonucleic acid from micro-organisms. $J$. Mol Biol, 3, 208-218.

[6] Nakagawa, M. (1984). Recent information on diagnosis and epizootiological features of Mycoplasma pulmonis infection in mice and rats. Exp. Anim. 33, 141-149.

[7] Razin, S., Harasawa, R., and Barile, M. F. (1983). Cleavage patterns of the mycoplasma chromosome, obtained by using restriction endonucleases, as indicators of genetic relatedness among strains. Int. J. Syst. Bacteriol, 33, 201-206.

[8] Razin, S. (1985). Molecular biology and genetics of mycoplasmas (Mollicutes). Microbiol. Rev., 49, 419455.

[9] Rogul, M., McGee, Z. A., Wittler, R.G., and Falkow, S. (1965). Nucleic acid homologies of selected bacteria, Lforms, and Mycoplasma species. J. Bacteriol, 90, 1200-1204.

[10] Sugino, W. M., Wek, R. C., and Kingsbury, D. T. (1980). Partial nucleotide sequence similarity within species of Mycoplasma and Acholeplasma. J. Gen. Microbiol, 121, 333-338.

[11] Watson, H. L., Davidson, M. K., Cox, N. R., Davis, J. K., Dybvig, K., and Cassell, G. H. (1987). Protein variability among strains of Mycoplasma pulmonis. Infect. Immun, 55, 2838-2840.

\section{げっ歯類由来マイコプラズマのゲノム D N A 解析}

国田智・寺田英司・合田朗・高倉 彰*・鍵山直子*

北里大学衛生学部実験動物学研究室

*(財)実験動物中央研究所

ゲっ歯類由来の代表的なマイコプラズマである $M y$ coplasma pulmonis, M. arthritidis, M. neurolyticumの 3 菌種間およびこれらの菌種の株間における ゲノム DNA の比較検討を行った。 3 菌種の DNA は, 明らかに異なる制限酵素切断パターンを示した。また， 全 DNA の交雑試験においても，3 菌種は遺伝的に異 なることが示された。一方，M. pulmonis 3株間怙よ
びM. neurolyticum 2 株間においては, DNA の制限 酵素切断パターンはほぼ同一であり，全 DNA の交雑 試験でも, 同一菌種の株間における遺伝的均一性が示さ れた。これらの成績は、げっ歯類に由来する各マイコプ ラズマ種のゲノムDNA の塩基配列が，高い種特異性 を有することを示唆している。 